\author{
Lenka Ř́hová, \\ PhD Student, Ing., University of Finance and Administration, \\ Research Worker at Research Institute for Labour and Social Affairs - RILSA (Prague, Czech Republic); \\ Karel Havlíček, \\ PhD, Associate Professor, Dean of the Faculty of Economic Studies, \\ Chairman of the BoD of the Association of Small and Medium Enterprises of the Czech Republic, \\ University of Finance and Administration (Prague, Czech Republic)
}

\title{
SPECIFICS OF PRICE MARKETING CONTROLLING AND PRICING OF PRODUCTS WITH SMALL AND MEDIUM-SIZED FAMILY ENTERPRISES
}

It is estimated that family enterprises participate in the entire global business by $80 \%$ share, while in the Czech Republic, family enterprises participate only by 20 to $30 \%$ in the gross domestic product, with the reason being the disruption of tradition of family businesses as a result of centrally planned economy. In case of small and medium family business the price is given exogenously, specifically by the situation on the market. Was found that the selection of the price calculation method is one of the critical controlling decisions. Thus, it can be said that consistent controlling management of small and medium-sized family businesses result in their increased competitiveness, it timely eliminates external risks, improves their stability and extends the life cycle and has a positive effects on the overall economic climate.

Keywords: management, controlling, calculation, small and medium enterprises, family enterprise, marketing, costs, competitiveness.

DOI: $10.21272 / \mathrm{mmi} .2017 .2-09$

Introduction. The basis of competitiveness of an enterprise in a hyper competitive environment $[5$, p. 39-54] is the maximum satisfaction of needs and expectations of customers, thus building a loyal clientele and stable position on the market. At the same time, it must generate the planned profit or free cash flow [13, p. 67] previously specified by the firm owner and to set a balanced relationship management with other stakeholders. A modern concept of customer relationship management $[10$, p. 35-48] is based on the application of the company or client marketing mix into all target groups of customers, among which are not only clients, but also suppliers, banks, employees, minorities or e.g. state, with result being the so-called client-oriented product, communication, price and distribution policy [10, p. 35-48].

Recent geopolitical changes characterized by the economic integration means that not only large companies but also small and medium-sized enterprises in fact have currently no barriers to conquer any global destinations. At the same time, they must face an unprecedented competition arising from opposite effort of producers from across the world to open their business and investment acquisitions in Europe, the European Union and in the Central Europe.

A fast development of information technologies characteristic by technological integration results in the escalation of the fight of firms for each and every client. The customers have available extensive information of products and their comparison with each of the suppliers. According to Association of Small and Medium Sized Enterprises and Czech Bank Association research about Electronic data processing from 2015, 95\% of the Czech small and medium-sized enterprises use the Internet and in accordance with findings of the Czech Statistical Office regarding the Use of Information and Communication Technologies in Households and among Individuals from 2014, 70\% of the Czech households have a connection to the Internet. The customers in both B2B and B2C areas have 
extensive information of products and use modern technologies to compare prices of the products offered.

Finally, the global economic crisis in 2008-2011 fundamentally transformed the behaviour of firms, including small and medium-sized enterprises that are more intensively dedicated to risk and potential crises management.

Analysis of recent researches and publications. For firms, and not only the family ones, it means that they have fundamentally changes their process management which is now based not only on planning, research, visions and missions but also on active controlling resulting in an increasing need to use fully price marketing controlling. As part of their research and publications, the authors have long examined the phenomena of small and medium-sized enterprises managed on the basis of M-C (Management- Controlling) process model.

M-C Model, the so-called Management-Controlling model is based on an interdisciplinary concept of SME management, based on an understanding of a relation between the strategic planning, operative planning, risk assessment and management. The process model of M-C based company management has been systematically dealt with by Karel Havliček, a co-author of this paper. In the publication "Role of managers in Company Management" [6, p. 72], he described the process planning and its relation to management activities. Subsequently, in the professional monograph - "Management\& Controlling of a Small and Medium-Sized Enterprise" [4, p. 210], he systematically dealt with the follow-up to the controlling process based on management accounting which also includes risk management.

The managerial activities in companies' management are based on the strategy definition [12, p. 57], and operative plans follow [4, p. 210]. The controlling departments (which are sometimes part of financial departments) are responsible for the control of future deviations from the set objectives and in small and medium-sized enterprises they are usually responsible for risk management arising from the established deviations. Due to the fact that each plan (both strategic and operative) must have defined goals, the controlling is oriented on detection and subsequent management of deviations of specific strategic and operative objectives. The entire model is based on SME specifics, including but not limited to:

- different system of owner relationship management (they are often part of executive management of SME),

- different system of financing, based on the enterprise balance sheet,

- different system of reporting of financial results, based on optimisation measures,

- different system of management of critical processes, based on personnel capacities,

- different system of management of supporting processes, based on the enterprise size.

The difference of SMEs arise from a long research of AMSP ČR in cooperation with Czech Statistical Office, which involved the total of 35 quantitative researches (CATI) oriented on the analysis of environment, identification of critical process planning and financial management of SMEs [1]. Each research included responses of more than 500 respondents, local small and medium-sized enterprises.

For the reasons above, the authors decided that the aim of this paper would be to analyse the problem of application of controlling in small and medium-sized enterprises with an emphasis on the price controlling and to show the importance of process controlling in a small and medium-sized family enterprise.

\section{Basic material}

1. Characteristics of small and medium-sized family enterprises. Family enterprises are in integral part of the majority of national economies. In the Czech Republic, as in other countries of the Eastern Europe the tradition of family business was disrupted as a result of centrally planned economy. According to long-term researches of AMSP ČR in cooperation with Czech Statistical Office, oriented on the analysis of family business of SMEs from years 2012-2015, family business participates in the gross 
domestic product of a country by only 20 to $30 \%$. Within the conference "Family Business on the European Platform - Competitive Edge and Challenges", at the Masaryk University, Brno (12.4. 2007), Professor Matti Koiranen said that approximately $80 \%$ of the total global business is owned by family enterprises. The situation in the Czech Republic and Eastern Europe is entirely different to the global situation, nevertheless we may assume that their share will grow as in similarly functioning market economies. There are many options how to characterize a family business and different states have different definitions of the term "family business". From the legal perspective, the business is defined as a continuous activity performed by the entrepreneur independently, under his name and responsibility in order to achieve profit. It can be derived from the above that one of the primary objectives of each entrepreneur is to generate profit. In the event of family business, the main objectives include keeping the firm for posterity.

In total, we may speak of three scopes of definitions of a family business:

1. Broad definition: in a family enterprise, the family has a strategic influence on further direction of the enterprise and the family also intends to keep the enterprise going. However, the family does not have to own a controlling interest of shares.

2. Medium definition: the family manages the enterprise and owns a controlling interest of shares.

3. Narrow definition: there are more family generations in the enterprise, they manage and own the enterprise with more than one family member having a major management position in the enterprise [7, p.7-15].

Therefore, the specifics of family business are always based on the involvement of family members in the management or direction of the business. For this reason, we need different set of rules for the management of small and medium-sized business as opposed to business that are not built on family relationships. As mentioned above, there are also specifics in the business objectives. In addition to traditional business objectives a personal goals of managers or owners, the family business must also take into account family objectives.

All these specifics give rise to a unique business culture and in-house relationships that may be extremely strong, but also prone to family conflicts that may jeopardize the very existence of the whole business.

Be it a family conflict in the family business or decision regarding the direction of the business or partial activities, there should be more emphasis on internal communication and etiquette in the family business as opposed to non-family business. Avoiding or resolving conflicts may be facilitate by a third party, being either an employee or professional who has no family ties in the business, but is involved in decisions regarding the business direction.

It follows a long-term research oriented at family business (which was conducted by AMSP CR in cooperation with Czech Statistical Office 2012-2015) in which the authors of the paper were involved that especially flexibility arising from a possibility to take fast decisions are among strengths of small and medium-sized family enterprises. As family business are not laden by the so-called bureaucratic rigidity. A psychological factor also plays an important role. The family is proud of its name and this is reflected in the total corporate identity and in the end, in the final product quality. In the event of family business, we may also assume a greater willingness to sacrifice free time of family member for commitment to the work for the business. It is based on an assumption that the whole family is dependent on the profit from the family business, not only a marginal portion of the family. Any loss or profit would this put the economic and social status of the whole family at risk. Their resilience in the times of crisis is yet another strength of family business when we may observe that family ties and will to keep the business are strong attributes ensuring longer life cycle of the enterprise [4, p.100-150].

According to the data from the research made by the Association of Small and Medium-Sized 
Enterprises in 2014 (AMSP CR and Czech Statistical Office research oriented on family business of SMEs), a generation change which is not survived by approx. $70 \%$ of business poses the greatest existential threat to family businesses. The situation is even more alarming due to the fact that the first massive handover of family business to younger generations is nearing and almost half of the family businesses has not yet started to resolve the succession issue. At the same time, we may assume that the family business with properly set controlling system, management and decision making has more chances to maintain its position and to continue to build its market position than family business who ignore this problem entirely. Another characteristics of family business is their higher inclination to tax optimisation which applies to small and medium-sized enterprise in general.

2. Controlling in the small and medium-sized family business. With the increasing speed of information flow, the multiple external effects on the market, industry and individual business escalates. Thus, the 21 st century becomes a turbulent marketplace where one must continuously respond and predict potential changes or development. It also brings the necessity to adjust the business management system and fully make use of controlling across the whole business. This management system can be defined as monitoring, discovering of deviations, designing measures and management of problematic and crisis situations. A comparison of the actually achieved results with the plan, finding and subsequently resolving deviations is at the core of the controlling [4, p.100-150].

According to Bohumil Král, the content of controlling is defined by two subsystems:

- subsystem of planning and control;

- subsystem of providing the information base [11, p. 19-41].

In particular, the integration of planning and control into a single subsystem is deemed to be the basis of an effective functioning of controlling. In total, the appeals is on consistent link between the plan and its control, using an appropriate information system.

At the same time, we differentiate between operative and strategic controlling [13, p.50-59]. The operative controlling focus on short-term plans and is usually evaluated based on quantitative parameters. On the contrary, the strategic controlling is oriented at long-term stability of the business. The evaluation of strategic objectives is done based on qualitative parameters and partially through quantitative parameters [5, p. 39-54].

The marketing controlling together with business, innovation and personal controlling, operative quality controlling and restructuring form a concept of a complex business controlling.

Even the marketing controlling itself is divided into strategic marketing controlling and operative marketing controlling. By its focus, the strategic marketing controlling aims at critical factors of long-term marketing, i.e. to the influence of the enterprise as a whole.

Therefore, the strategic marketing controlling focuses on the following areas:

- macroenvironment: monitoring and evaluation of sociological, macroeconomic, technology, environmental and business factors, such as using STEEP analysis;

- internal environment: analysis of impacts inside the business and its close vicinity, e.g. SWOT analysis;

- pricing strategy;

- image of the brand;

- life cycle of the product or service.

As opposed to the this, the operative marketing controlling is more oriented at:

- monitoring of competitive environment;

- distribution paths and their optimisation: special attention is paid to international markets in case of distribution;

- segmentation monitoring: specifically small and medium-sized enterprises have an effective 
targeting to these segments that yield the highest expected income. As opposed to large companies, small and medium-sized enterprises may not serve loss-yielding clients;

- the product mix and optimisation of product lines: most critical in manufacturing companies. Here, controlling has a role of a moderator between the section of marketing, business, manufacture, logistics and quality:;

- optimisaton of communication [5, p. 39-54].

As opposed to the controlling of other business processes, controlling of marketing activities is more challenging and often neglected in small and medium-sized enterprises. Even more so, the controlling is underestimated by family businesses, as family ties often lead to unwillingness to assume responsibility for wrong strategy or operative goals. The minimisation of external managers at the controlling level in order to keep some information, especially of an accounting character, secret is another reason why controlling fails in family businesses. Family members acting as controller do not fulfil his critical mission to discover faults of the management in timely manner, to calculate negative variations of future performance and to ensure the business in periods of growth for future crises. Particularly, the calculation of failures of marketing objectives, as the basis of marketing controlling will not show immediately, but with some delay. However, to respond to the failure of marketing researches, plans and targets only when the production or relationships with clients are disrupted may prove fatal for the business.

Therefore, the controller has a key role for healthy functioning of the business. However, there is still an issue who should hold such position in family businesses. The current research [2] shows that if we speak of micro businesses with 10 employees at maximum or small enterprises with the total of 50 employees at maximum, the role of the controller is assumed as one of his many competences, the owner or manager, i.e. a family member. With regard to medium-sized enterprises there is both a room for a position of an independent controller and implementation of the controlling process into the business process management. In such cases, the controller has a role of a top manager who is in close contact with both company management and the employees as well. If the controller has no family ties to the business, it becomes a key benefit both for the business as such and each of the family members too. He may act as some kind of a counsellor giving recommendations and in the event of conflicts among family members in management positions may tone down emotional discussions. On the other hand, there is an danger of mistrust of family members in management position in crisis situations when a strategic decision need to be taken. Therefore, it is desirable in all situations that exact rules and competences of individual staff members are defined.

3. Product pricing and role of controlling. From the client perspective, the price of the product or service is one of the key factors that are decisive for potential purchase. In the same manner as the price is important for the customer, the price has key importance for the business too. The business addresses the issue of the price amount in times when it introduced a an already existing product in the market, launches an innovative product, or if the product passes to another phase of the life cycle, or if the pricing conditions change, i.e. sudden change of the price of raw materials, tax system and so on [11, p. 46-64]. At the same time, new players, competition, or global fashion trends etc. may enter the market. Therefore, a continuous controlling has a key role.

When adequate price is being set, both internal and external factors must be taken into account. Internal influences are fixed and variable costs together with the requirement for profit. Therefore, the business turning point, i.e. situation when the production volume equals total costs, must be taken into account [13, p.70-150].

Figure 1 illustrates that the Breakeven point is reached when the price equals average costs (sum of fixed costs per production unit and variable costs per production unit). In this situation, the business 
does not generate income, respectively generates zero economic profit [13, p. 70-150].

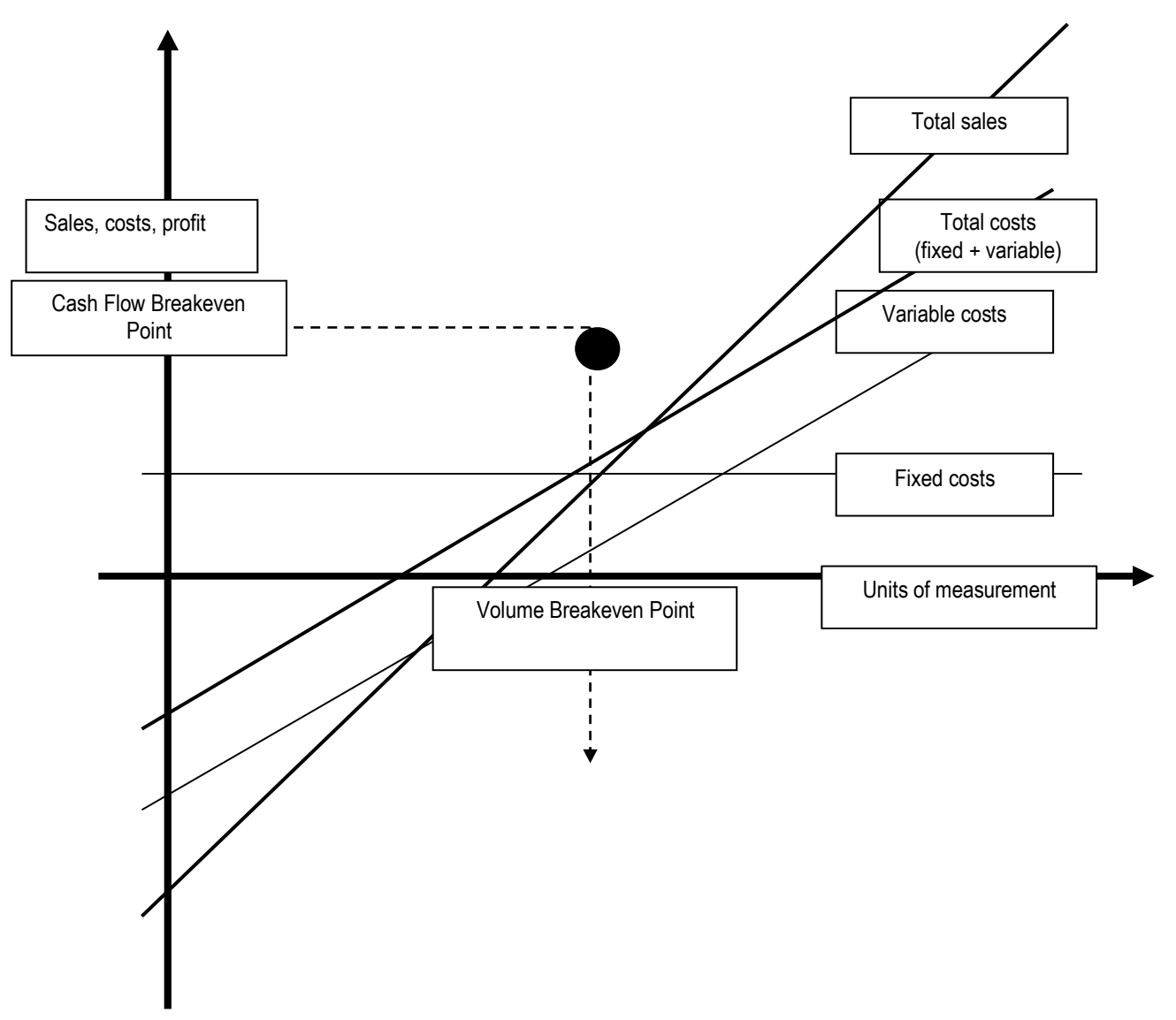

Figure 1 - Breakeven Point [4, p.170-175]

Precise determination of the turning point can only be determined by minimum production volume, respective the degree of how production capacities are utilized [3, p.15-40]. For this reason, the information about the turning point is important for both financial and marketing controlling.

Other factors that are in play for product pricing are external effects, i.e. price of competition and expectations of customers. Small and medium-sized family business have a rather marginal market share and thus the monitoring of external effects, especially of the prices of competition, is critical for successful functioning of the business. The pressure of the competition to price makes small and medium businesses, including family business to adjust internal factors to market requirements.

The demand price, i.e. the current price on the market, is a representation of a maximum limit that the customer are willing to pay for the given product. On the contrary, the supply price is the minimum limit that is still beneficial to businesses, i.e. the business is able to pay for its costs [11, p. 97-120]. To obtain this information regarding the demand price is entirely within the competence of marketing department, the calculation of the cost price is then within the competence of the controlling department. 
The equilibrium price is the the ideal situation when supply price and demand price meet [8, p. 53-85]. The customers are satisfied and show sufficient interest in products. When equilibrium price is reached businesses pay their costs from the economic point-of-view. Therefore, there is neither any surplus nor shortage. Seemingly it may appear that a relatively high price is more beneficial for the business as they can make more profit. From the perspective of small and medium-sized family enterprises it may be the case, but only in short time horizon. In the long run, high prices decrease the demand of customers. Thus, there is higher pressure on lower price driving less competitive businesses out of the market. By this process, the price will strike an equilibrium again. On the contrary, the lower price than the equilibrium one positively stimulates the demand, however with the result being short-term losses for the company.

In case of small and medium family business the price is given exogenously, specifically by the situation on the market $[6, p .14]$. For this reason, the information regarding the current activity on the market is critical. Small and medium-sized business functional on markets of monopoly competition, i.e. numerous representation of competing firms with relatively similar economic strength, the products of which are not homogeneous, but may be substituted [11, p. 97-120]. For the client's point-of-view, their differentiating characteristics consist mostly in the service, distribution network and of course, quality. Therefore, small and medium-sized businesses try to gain external completive edge. Due to the market characteristics, there is a potential to fully utilize marketing activities to attract customers.

It can be said based on the above and long-term research that marketing activity has more effect on pricing with small and medium business than in large businesses. This is given by the fact that external effects (demand of customers and prices of competition) have much more influence to the behaviour of small and medium-sized enterprises, including family business than to large corporations. As opposed to large enterprises, family businesses must adjust prices of their products to external effects and fixed and variable costs internal effect) must be adjusted accordingly to the market situation. On the contrary, large corporations with a dominant market share may partially ignore external effects and adjust prices of products only to internal effects. Therefore, it may be said that requirements of the ability of marketing staff to work flexibly with the market are higher in small and medium family business than of the marketing staff working in large corporations.

4. Demand-oriented pricing methods. Exact definition of a specific relation of the amount demanded by customers and product selling price is fundamental for each small and medium family enterprise, both from the competitiveness and profit generation perspective. The prediction of demand flexibility, i.e. how the demand will respond to the price change and what impact the price will have on proceeds from sale is not an easy one and in real market environment often an impossible one. The calculation of price flexibility is given by the percentage share of the change of the amount of products and percentage change of the product price.

Figure 2- Options of price flexibility of the demand [11, p. 530-594]

\begin{tabular}{|l|l|}
\hline \multicolumn{1}{|c|}{ Price flexibility of the demand } & \multicolumn{1}{c|}{ Flexibility type } \\
\hline Higher than 1 & Relatively flexible demand \\
\hline Less than 1 & Relatively rigid demand \\
\hline Equals 1 & Flexible demand per unit \\
\hline
\end{tabular}

A relatively flexible demand is an ideal situation for every business. If such demand reached, the percentage of the increase of the goods sold is higher for the firm than percentage price reduction. The price reduction is thus compensated by increased sale volume. To increase profit such business 
must have total increase of sale revenues higher than additional variable costs. A different situation occurs with a relatively rigid demand where the percentage increased of the amount of the products sold is less than the percentage price reduction. There may be many reasons why the business decides to reduce the price of products in such situation, including competition or vision to take higher market share. At any case, business will sacrifice short-term maximum profit. Whether or not such step will be beneficial to the business in the long run is a question of specific objectives and motives of the business. A third option of a price flexibility of the demand is the flexible demand per unit when the percentage reduction of the product price is compensated by identical increase of the sale volume, and the total revenues thus remain constant.

In reality, there is a problem of the number of effects influencing the decisions of the customers at any given moment when the price flexibility is being determined. It follows from the above that the analysis of price flexibility always yields only approximate data. The client's decision is influenced not only by the price of the given product, but also the price of substitution or complementary products, together with psychological and social factors, such as current global trends, momentary emotions of the client and so on. One of the main benefits of family business as shown by the research of the Association of Small and Medium-Sized Enterprises, is seen in their flexibility according to family business themselves. This stability should also concern price fluctuations which may not be beneficial in the event of small and medium-sized businesses. The fluctuations in price products may result in the loss of trust of customers and harm the firm in the long run.

The key issue remains whether the profit is generated with the higher product price and less sale volume or lower price and higher sale volume [11, p. 530-594]. Therefore, it is possible to apply the policy of low price, the so-called penetration or opposite price policy, the so-called price skimming [9, p. 13-36]. However, it always depends on the particular market when the business is active, possibilities of the given business, such as sufficient long-term capital, and also on price sensitivity of clients, ale but also on the product life cycle.

Price setting according to the development of the demand, the so-called empirical pricing is another approach towards the price setting [9, p. 215-239]. Based on the poll, the customers is interviewed what is the minimum and maximum price he would be willing to pay for the product. However, the relevance of the client data gathered is the weakness of the empirical pricing. The responses of clients may differ from their real behaviour while making a purchase.

At the same time, we must remember, and the research among enterprise proves this trend, that other factors of a controlling nature come into play. The sale of higher quantity of goods with less added value is dangerous for small and medium businesses due to an increased risk of claim management. Outstanding claims are the most frequent reason for the bankruptcy of small and medium business, family enterprises included. If the business has a large number of claims against its customers and achieves only low added value, failure to settle of a portion of these claims, may liquidate the business, as the margin will neither cover the loss of cash nor economic result.

On the contrary, lower quantity of claims and higher added value eliminates this risk. This is shown in the business case management on international markets where higher prices must achieved in riskentailing territories, and in more stable countries lower prices can be accepted. For this reason, according to AMSP ČR (Trade and Investment Activities between the Czech Republic and the USA 2015), the market of the United States of America where high added value is achieved and the market is sufficiently large even for increase of sales becomes a very attractive territory for small and mediumsized European enterprises.

5. Cost-oriented pricing methods. Not only is the pricing dependent on external factors that are analysed in more detail in the previous section, but also on internal factors, i.e. costs and requirement on 
the profit.

For cost-oriented pricing methods, the setting of guide price is the most important thing. The guide price is such price amount which under the given circumstances of the sale volume will yield the required profit to the business.

On the basis of the guide price and market selling price the calculation related to the market distribution, cost development and so on will be made [11, p. 530-559]. These calculations are closely related to the main business budget and parts thereof, particularly to the sale plan, budgeted revenues and many more.

The calculation of the guide price consists of two main parts, from the calculation of costs and setting of profit margin. The amount of the expected profit, included in the product price, should be equal to the expected appreciation of the invested capital [11, p.530-559].

The calculation of costs then serves as the basis for the price calculation itself and has a direct impact on the price. The cost calculation is an overview of specific cost components that are subsequently calculated under calculation items that are shown in the calculation formula.

Choosing the most suitable calculation method is thus one of the main tasks of controlling decisions that should be based on the nature of the business of the given enterprise. The main calculation method utilized are calculation by division and surcharge calculation [4, p.10-210].

The calculation by division is based on the assignment of the costs of production to the amount of differently expressed calculation units. The surcharge calculation is mostly used by companies that focus on the production of higher numbers of different products. The principle consists in the division of costs to direct and indirect costs.

The failure to utilize such price calculations may be fatal for small and medium-sized enterprises and business that do not utilize such calculations are able to accept high levels of risk. Therefore, we may infer that these businesses do not realize the level of risks taken and the reason why they do not utilize calculations is that they are not aware that such calculations exist.

With an aim to establish the level and reasons of utilization of different calculation approaches, Růžena Kafková made a representative research in 2015, the results of which were presented at the 2015 Conference of Postgraduate Students organised by Vysoká škola finanční a správní, o.p.s. (University of Finance and Administration). 112 business participated in the research and the research showed that the surcharge calculation is utilized by $49 \%$ of business, with $38 \%$ of business using the calculation by division, and $1.5 \%$ of businesses utilize both calculations, however almost $11.5 \%$ of businesses use other methods, estimates or no calculations at all.

Conclusion. Family enterprises are in integral part of the majority of national economies. It is estimated that family enterprises participate in the entire global business by $80 \%$ share, while in the Czech Republic, family enterprises participate only by 20 to $30 \%$ in the gross domestic product, with the reason being the disruption of tradition of family businesses as a result of centrally planned economy.

Small and medium-sized businesses are active in the marketplace with features of monopoly competition. Therefore, in the pricing of products and services they must predominantly orient themselves by external factors, such as price of the competition and client expectations. The family businesses are often forced to adjust internal factors to market requirements.

The role of marketing department in the pricing is higher with small and medium-sized businesses than with large corporations. This brings us to another conclusion that small and medium-sized businesses must be more flexible from the marketing perspective and that in many aspects, requirements on the marketing staff members are more demanding than with large corporations.

In case of small and medium family business the price is given exogenously, specifically by the situation on the market. For this reason, the information regarding the current activity on the market is 
critical. To obtain this information regarding the demand price is entirely within the competence of marketing department, the calculation of the cost price is then within the competence of the controlling department.

The selection of the price calculation method is one of the critical controlling decisions. The calculation by division and surcharge calculation are the most utilized methods.

In short-term the business, e.g. for competition reasons, resort to the setting of lower product prices than the equilibrium price. This results in a shot-term loss for the business. High degree of fluctuations in price products may however result in the loss of trust of customers and harm the firm in the long run. On the other hand, low price levels in combination with higher volumes of sales increase the risk of management of outstanding claims, and the risk increases particularly on international markets where the probability of default is higher than in the local environment. It follows from the above that on riskentailing market, higher prices must be achieved.

The turbulent features of the 21st century marketplace make the need of controlling across the whole company even more pronounced. However, controlling activities are often neglected by smaller companies, and the ignorance of the marketplace and failure of marketing plans may result in destabilization of the enterprise in the long run.

Thus, it can be said that consistent controlling management of small and medium-sized family businesses result in their increased competitiveness, it timely eliminates external risks, improves their stability and extends the life cycle and has a positive effects on the overall economic climate.

Acknowledgement. The paper has been prepared under the project "Current trends in development of financial markets", supported by the Institutional support for long-term strategic development of research organization University of Finance andnAdministration.

1. Association of Small and Medium-Sized Enterprises and Crafts of the Czech. (2010-2015). Research of AMSP ČR in cooperation with Czech Statistical Office, which involved the total of 35 quantitative researches (CATI) oriented on the analysis of environment, identification of critical process planning and financial management of SMEs. Each research included responses of more than 500 respondents, local small and medium-sized enterprises. Retrieved from http://www.amsp.cz/ [in Czech].

2. Czech Statistical Office. (2014). Use of Information and Communication Technologies in Households and among Individuals. www.czso.cz. Retrieved from https://www.czso.cz/csu/czso/vyuzivani-informacnich-a-komunikacnich-technologii-vdomacnostech-a-mezi-jednotlivci-2014-ejgbbmx0ui [in Czech].

3. Fotr, J., \& Souček, I. (2011). Investment decision and project management. Prague, Grada Publishing [in Czech].

4. Havliček, K. (2011). Management \& controlling of SMEs. Prague, University of Finance and Administration. Eupress [in Czech].

5. Havliček, K. (2011). Marketing Management and Marketing Controlling of SMEs. European Research Studies, 14(4), 39-54. Piraeus. Retrieved from http://www.ersj.eu/repec/ers/papers/11_4_p3.pdf [in English].

6. Havliček, K. (2009). Role of managers in Company Management. Prague, University of Finance and Administration. Eupress [in Czech].

7. Hesková, M., Hurtová, J., \& Vojtko, V. (2008). Family business - source of regional development. Prague, Profess Consulting [in Czech].

8. Holman, R. (2011). Economy. 5. edition. Prague, C.H. Beck [in Czech].

9. Jakubíková, D. (2008). Strategic management - Strategy and trends. Prague, Grada Publishing [in Czech].

10. Kotler, P. (2007). Modern marketing. 4th European edition, Prague, Grada Publishing [in Czech].

11. Král, B. (2010). Management accounting. 3rd updated edition. Prague, Management Press [in Czech].

12. Mallya ,T. (2007) Principles of Strategic Management and Decision Making. Prague, Grada publishing [in Czech].

13. Synek, M. (2011). Management Economics. 5. updated edition. Prague, Grada Publishing [in Czech]

Л. Ржигова, аспірант, Ing., Університет фінансів та управління, науковий співробітник Науково-дослідного інституту праці та соціальних питань (Прага, Чеська Республіка);

К. Гавличек, PhD, доцент, декан факультету економічних досліджень, Голова Ради директорів Асоціації малих і 
середніх підприємств у Чеській Республіці, Університет фінансів та управління (Прага, Чеська Республіка)

Особливості ціноутворення та контролю за цінами на продукцію малих і середніх сімейних підприємств

Визначено, що у світовій економіці частка сімейних підприємств становить $80 \%$, у той самий час у Чехії частка сімейних підприємств є рівною 20-30\%, що є результатом централізованої планової економіки. Встановлено, що на малих і середніх підприємствах ціни встановлюються екзогенно, зокрема, на основі врахування ситуації, що склалася на ринку. У ході дослідження було з'ясовано, що вибір методу розрахунку цін $є$ одним із найважливіших управлінських рішень на малих і середніх сімейних підприємствах. Також визначено, що послідовне управління малими та середніми сімейними підприємствами дозволяє підвищити їх конкурентоспроможність, своєчасно усунути зовнішні ризики, підвищити їх стабільність, подовжити життєвий иикл, а також чинить позитивний вплив на загальний економічний клімат у країні.

Ключові слова: управління, контроль, розрахунок, малі та середні підприємства, сімейне підприємство, маркетинг, витрати, конкурентоспроможність.

Л. Ржигова, аспирант, Ing., Университет финансов и управления, научный сотрудник Научно-исследовательского института труда и социальных вопросов (Прага, Чешская Республика);

К. Гавличек, PhD, доцент, декан факультета экономических исследований, Председатель Совета директоров Ассоциации малых и средних предприятий в Чешской Республике, Университет финансов и управления (Прага, Чешская Республика)

Особенности ценообразования и контроля за ценами на продукцию малых и средних семейных предприятий

Определено, что в мировой экономике доля семейных предприятий составляет $80 \%$, в то же время в Чехии доля семейных предприятий является равной 20-30\%, что является результатом централизованной плановой экономики. Установлено, что на малых и средних предприятиях цены устанавливаются экзогенно, в частности, на основе учета ситуации на рынке. В ходе исследования было выяснено, что выбор метода расчета цен является одним из важнейших управленческих решений на малых и средних семейных предприятиях. Также определено, что последовательное управление мальми и средними семейными предприятиями позволяет повысить их конкурентоспособность, своевременно устранить внешние риски, повысить их стабильность, удлинить жизненный иикл, а также оказывает положительное влияние на общий экономический климат в стране.

Ключевые слова: управление, контроль, расчет, малые и средние предприятия, семейное предприятие, маркетинг, расходы, конкурентоспособность.

Отримано 06.05.2016 p. 